N. M. Fialko, orcid.org/0000-0003-0116-7673, R. O. Navrodska, orcid.org/0000-0001-7476-2962, S. I. Shevchuk, orcid.org/0000-0001-8046-0039, A. I. Stepanova, orcid.org/0000-0002-9297-8473
Institute of Engineering Thermophysics of National Academy of Sciences of Ukraine, Kyiv, Ukraine, e-mail: navrodska-ittf@ ukr.net

\title{
IMPROVEMENT OF ENVIRONMENTAL CONDITIONS BY APPLYING HEAT RECOVERY TECHNOLOGIES OF BOILER PLANTS
}

Purpose. Analysis of the effectiveness of using methods of heat and humidity treatment of flue gases to improve the operational modes of chimneys for heating gas-consuming boiler plants with heat recovery systems.

Methodology. The known normative methods of thermal calculation of boiler plants and methods of dispersion of pollutants emitted by chimneys of these plants were used. To determine the thermal and moisture parameters of flue gases during their deep cooling, an original method developed at the Institute of Engineering Thermophysics of the National Academy of Sciences of Ukraine was used.

Findings. The efficiency of applying the proposed thermal methods to improve environmental conditions and magnification of the operational reliability of chimneys of boiler plants equipped with systems for deep heat recovery of exhaust gases has been studied. The methods which are usually used in boiler-houses to prevent condensate formation in chimneys were considered. A decrease in the maximum ground-level concentration of nitrogen oxides and carbon monoxide emissions was determined when using these methods. A comparative analysis of the effectiveness of the proposed methods for brick and metal chimneys in different modes of operation of heating boiler plants has been carried out. It is shown that these methods allow improving significantly (up to $32 \%$ ) the indicators of ecological efficiency of chimneys in conditions of 5-8\% reduction of fuel use in boilers.

Originality. For the first time to improve the environmental performance of chimneys of boiler plants with deep heat recovery systems of flue gases has been justified the use of thermal methods of their heat and moisture treatment.

Practical value. The possibility of using the results of the work in the design of heat recovery systems for gas-consuming heating boilers.

Keywords: heat recovery systems, methods of heat and humidity treatment, flue gases, harmful emissions, ecological efficiency

Introduction. Modern trends in the use of fuel-consuming thermal power plants are largely related to the need to reduce fuel consumption in these units, that is, to increase their efficiency or the coefficient of the use of fuel heat. This reduction is usually realized through the use of various heat recovery technologies [1-5]. In work [1], it was proposed to use the heat of waste flue gases from boilers to heat water and evaluated the economic efficiency of this solution. Scientific publication [2] is devoted to the methodology of recovered of waste heat of various fuel-consuming technological installations used in industry. The work [3] considers the issues of increasing the efficiency of fuel use in heat-exchange elements of nuclear power plants applying the exergy approach methods. In the work [4] the results of exergy and exergy-economic analysis for the elements of power plants, the efficiency of which is evaluated at different ambient temperatures, are presented. In the works by Yefimov [5], approaches to improve and optimize the equipment of deep heat recovery systems of water-heating and steam boilers of municipal heat-power engineering are proposed. The use of heat recovery technologies, in addition to the positive effect of decreasing fuel consumption, quite often leads to negative deviations of the actual modes of operation of chimneys compared to regulatory requirements. The indicated deviations also occur when the heat load of thermal power plants is reduced compared to the design values. These deviations have both positive consequences (decrease in temperature of exhaust gases and volume of harmful emissions) and negative consequences (violation of chimney operation modes in terms of safety of their operation and dispersion of pollutants in the environment). Corrosive destruction of chimneys also belongs to the negative consequences. Particularly in boiler plants, this destruction is caused by condensation due to a decrease in the temperature of the inner surface of chimneys below the dew point of water vapor that the flue gases contain $[6,7]$.

(c) Fialko N. M., Navrodska R. O., Shevchuk S. I., Stepanova A. I., 2021
Metal chimneys experience the greatest corrosive effects due to the deeper cooling of flue gases in them [6], which causes more intense condensation on the inner surfaces of the pipe. Brick chimneys also experience corrosive wear of their body during condensation [7]. Given this, condensation is considered to be an inhibiting factor for the widespread introduction of efficient heat recovery technologies with deep cooling of exhaust gases and useful use of the condensation heat of water vapor contained in these gases. To prevent condensation formation on the inner surfaces of the gas outlet channels, special thermal methods are used. Among these methods, a number of methods related to heat and humidity treatment of flue gases after their heat recovery particularly stands out $[8,9]$. The implementation of these methods consists in changing the thermal and humidity state of these gases, namely increasing their temperature and decreasing their absolute or relative humidity by applying three methods. These methods are implemented bypassing a certain part of the flue gases from the boiler by the bypass gas duct past the heat recovery equipment; adding heated air to the exhaust gases after cooling and heating the cooled gases in a special heat exchanger (gas preheater) installed behind the specified equipment. It should be noted that thermal methods are effective in the case of deep cooling of flue gases during their heat recovery, that is, when the temperature of flue gases at the outlet of the heat exchanger decreases below the dew point of water vapor contained in these gases.

If the bypass method is used, the temperature of the flue gases at the inlet to the chimney increases and their moisture content increases compared to the flue gases after the heat recovery unit. The method of heating gases serves to increase the temperature of gases cooled in a heat exchanger before entering the chimney at a constant moisture content of these gases. Application of the method for adding dry and heated air to the flue gases after the heat recovery unit provides both an increase in the temperature of these gases before the 
chimney and a decrease in their moisture content. The applied methods can simultaneously serve to improve the environmental performance of chimneys, since they increase the temperature and velocity of flue gases at the exit from the chimney orifice. These characteristics significantly affect the conditions of dispersion in the environment of harmful emissions from fuel combustion. That is, the application of these thermal methods will serve to improve environmental conditions.

The purpose of the research is to analyze the efficiency of using methods of heat and moisture treatment of exhaust gases after their cooling to improve the operating modes of chimneys for gas-consuming heating boiler plants with heat recovery systems.

Methods. The implementation of computational studies was mainly based on the use of normative methods of thermal calculation of boiler plants [10] and the methodology (Severin L. I., Petruk V. G., Bezvoziuk I. I., Vasylkivskyi I. V., 2012) of dispersion in the ground-level layer of pollutants emitted by the chimneys of these plants. To determine the thermal and humidity indicators of exhaust gases during their deep cooling, an original technique developed at the Institute of Engineering Thermophysics of the National Academy of Sciences of Ukraine was used. This technique is based on taking into account the effect of steam condensation from flue gases in heat recovery equipment.

When developing this technique, the results of our own experimental studies were used in conditions of deep cooling of the exhaust flue gases of gas-consuming boiler plants in bundles of finned bimetallic pipes (steel base and aluminum fins).

The work considered the methods of heat and humidity treatment of exhaust gases cooled in the process of heat recovery. These methods, as noted, are used in modern heat recovery technologies of boiler plants for the purpose of anticorrosive protection of chimneys. The influence of these methods on the improvement of the ecological modes of operation of chimneys is realized due to an increase in their temperature, and, consequently, the speed in the chimney. Schematic diagrams of boiler plants with water-heating recovery exchanger for waste gases are shown in Fig. 1.

The red line in the diagrams shows the implementation of the method of bypassing part of the hot flue gases from the boiler into its exhaust gas duct in front of the chimney past the heat recovery equipment. The brown line in the figure corre-

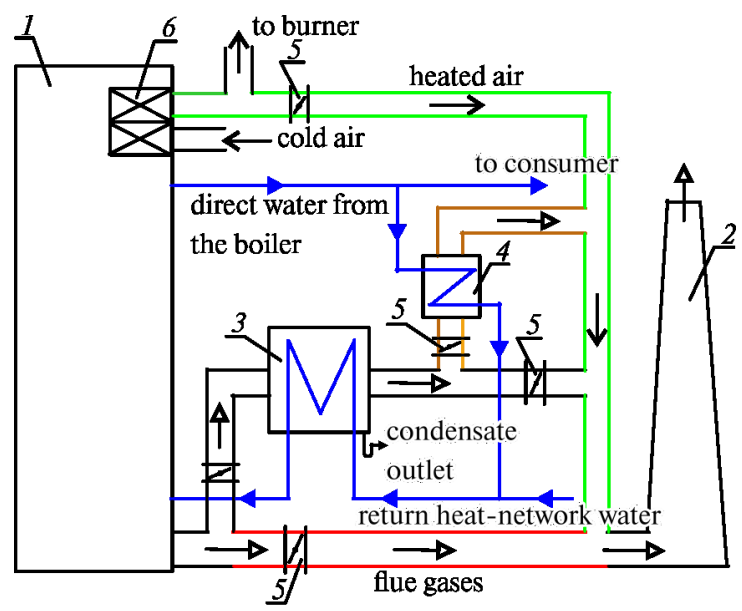

Fig. 1. Schemes of implementation of thermal methods of heat and humidity treatment of exhaust gases after heat recovery before they enter the chimney:

bypassing a part of the boiler exhaust gases past the heat recovery unit; _ _ - adding heated air to the flue gases after the heat recovery unit; __ - heating of cooled exhaust gases in the gas preheater; 1 - boiler; 2 -chimney; 3 -water-heating recovery exchanger; 4-gas preheater; 5-control valve; 6-boiler air heater sponds to the application of the heating method in the heat exchanger-gas preheater by the value $\Delta t$ of the exhaust gases cooled in the heat exchanger. The green line in the diagram indicates the method of adding (mixing) the share $\sigma$ of heated air from the boiler air heater to the cooled gases in front of the chimney. The mentioned thermal methods in the application of heat recovery technologies with deep cooling of flue gases will serve both for corrosion protection of chimneys and improvement of environmental conditions.

The studies were carried out in compliance with the design values of the heat output of boiler houses for a water-heating boiler plant with a boiler BSHW-2.0G (steel hot water gas boiler with a capacity of $2 \mathrm{MW}$ ). The application of traditional heat recovery systems with heat recovery exchangers designed for heating return heat-network water was considered. The use of these heat exchangers makes it possible to increase the boiler efficiency by $5-8 \%$. This equipment is assembled from bundles of finned bimetallic pipes (aluminum fins and steel base). The bundles used steel pipes with an inner diameter of $25 \mathrm{~mm}$ and a thickness of $2.5 \mathrm{~mm}$. The thickness of the aluminum on the steel pipe, the finning height and the fin spacing were $2.0,11$, and $3.5 \mathrm{~mm}$ respectively.

The boiler modes corresponded to the heating network schedule of the boiler house with a temperature differential $\Delta t_{h}=115-70{ }^{\circ} \mathrm{C}$. The temperature of the exhaust flue gases behind the boiler in the nominal mode was $166^{\circ} \mathrm{C}$. The temperature of the mixed air was taken equal to $150{ }^{\circ} \mathrm{C}$. The levels of hot gas bypass $\chi$, air mixing $\sigma$ and heating of cooled gases in the gas heater $\Delta t$ corresponded to the practical range of values required to prevent condensation in the chimneys [8].

Metal and brick chimneys with a height of $45 \mathrm{~m}$ and an inner diameter of $0.8 \mathrm{~m}$ were considered. The regime parameters of flue gases (velocity and temperature) at the outlet from the orifice of the chimney were determined. The levels of maximum ground-level concentrations of the most harmful emissions of gas-consuming boiler plants, such as carbon monoxide $\mathrm{CO}$ and nitrogen oxides $\mathrm{NO}_{x}$, were calculated. The calculations were performed for single chimneys.

The maximum ground-level concentrations of harmful emissions in the surrounding space of the chimney were determined in accordance with the methodological recommendations

$$
C_{m}=\frac{A M F m m}{H^{2} \sqrt[3]{V \Delta t}},
$$

where $A$ is a coefficient depending on the temperature gradient of the atmosphere; $M$ is the estimated mass of a hazardous substance that is emitted into the atmosphere per unit time, coefficient $F$, which takes into account the sedimentation rate of harmful substances in the atmosphere for gases; $\eta$ is the coefficient of terrain influence, $m$ and $n$ are calculated dimensionless coefficients, taking into account the conditions for the exit of flue gases from the pipe orifice; $H$ is chimney height, m; $V$ is the volume flow of waste gases; $\Delta t$ is the difference between the temperature of the flue gases from the chimney mouth $t_{\text {ori }}$ and the ambient temperature $t_{a m b}$.

When performing computational studies for the conditions under consideration, coefficient $A$ was taken as the maximum value of 200. Coefficients $F$ and $\eta$ were taken equal to one, coefficients $m=0.98-1.23$ and $n=1.14-1.87$; pipe height $H==45 \mathrm{~m}$. The values of calculated emission masses of nitrogen oxides $M^{\mathrm{NO}_{x}}$ and carbon monoxide $M^{\mathrm{CO}}$ were calculated at maximum allowable values of the content of these harmful substances in flue gases 250 and $100 \mathrm{mg} / \mathrm{m}^{3}$ respectively. These values were $M^{\mathrm{NO}_{x}}=1.06-0.31$ and $M^{\mathrm{CO}}=$ $=0.42-0.12 \mathrm{~g} / \mathrm{s}$; waste gas volume flow $V$ and the difference $t$ varied depending on the boiler output and the conditions of each method. Their values were $V=5.7-1.4 \mathrm{~m}^{3} / \mathrm{s}$ and $t=40$ $140{ }^{\circ} \mathrm{C}$.

Based on the values of the determined ground-level concentrations, the relative decrease in $C_{r e l}^{\mathrm{CO}}$ and $C_{r e l}^{\mathrm{NO}_{x}}$ concen- 
trations of harmful emissions under the conditions of applying the methods $C_{m}$ compared to the situation without their application $C_{o}$ were calculated

$$
\begin{gathered}
C_{r e l}^{\mathrm{NO}_{x}}=\left(C_{o}^{\mathrm{NO}_{x}}-C_{m}^{\mathrm{NO}_{x}}\right) / C_{o}^{\mathrm{NO}_{x}} \cdot 100 \% ; \\
C_{r e l}^{\mathrm{CO}}=\left(C_{o}^{\mathrm{CO}}-C_{m}^{\mathrm{CO}}\right) / C_{o}^{C O} \cdot 100 \% .
\end{gathered}
$$

Results. Computational studies of operating parameters (temperature $t_{o r i}$ and velocity $W_{o r i}$ of flue gases at the outlet from the chimney mouth) were carried out depending on the relative heating capacity of the boiler $Q_{b}$ for the two types of considered chimneys. The results of the corresponding calculations are shown in Table 1 and in Fig. 2.

The obtained results showed that the value of flue gas velocity $W_{\text {ori }}$ varies for the considered methods, depending on the operating characteristics of the boiler in the range from 2.9 to $14 \mathrm{~m} / \mathrm{s}$. These speeds increase monotonically with increasing relative boiler output $Q_{\mathrm{b}}$, but do not significantly depend on the method used and its parameters. For the method for adding air, the calculated velocity values were slightly higher due to the increase in the volume of flue gases in the chimney by a share $\sigma$ of the heated air being added.

The flue gas temperature values $t_{\text {ori }}$ at the outlet from the chimney orifice changed more significantly than the velocity $W_{o r i}$. As can be seen from Fig. 2, $a$ (Fig. 1, red line), the temperature $t_{\text {ori }}$ increase with increasing relative boiler capacity $Q_{b}$ and parts $\chi$ of bypassing exhaust gases past the heat recovery equipment. Moreover, the influence of the boiler output is more significant than the volume of bypassing hot gases from the boiler. Parts of bypassing correspond to practical values when using the considered thermal method for anticorrosive protection of chimneys. The results indicate that the larger this part is, the stronger the stratification of the curves $t_{\text {ori }}=f\left(Q_{b}\right)$ is, especially for a metal pipe, which corresponds to higher values of $\chi$ than for a brick one.

Thus, the use of the thermal bypass method, all other things being equal, improves the operating parameters of the chimney to improve the conditions for the dispersion of harmful substances in the environment.

Table 1

The ranges of flue gas velocity change $W_{\text {ori }}$ at the outlet of the orifice for the applied thermal methods

\begin{tabular}{|l|c|}
\hline \multicolumn{1}{|c|}{ Thermal methods } & $\begin{array}{c}\text { Values } \\
W_{\text {ori }}, \mathrm{m} / \mathrm{s}\end{array}$ \\
\hline Gas bypassing & $12.6-2.9$ \\
\hline Heating of gases in the gas preheater & $12.9-2.9$ \\
\hline Adding heated air & $14.0-2.9$ \\
\hline
\end{tabular}

The study on application efficiency of the cooled exhaust gases heating method in a heat exchanger-gas preheater (Figs. 2, $b$ and 1, brown line) evidences the same tendencies. However, the obtained calculated values of temperatures at the chimney orifice $t_{o r i}$ for the heating method are slightly higher compared to the bypass method. This circumstance testifies to the high efficiency of the application of the cooled exhaust gas heating method in terms of improving the environmental performance of chimneys at the indicated levels of gas heating. However, the application of the exhaust gas heating method requires capital expenditures for the installation of a heat exchanger-gas preheater in the heat recovery system.

The results of studies on the method of adding heated air to the flue gases cooled in a heat exchanger (Figs. 2, $c$ and 1, green line) also indicate its effectiveness for use to improve the conditions for the dispersion of harmful substances contained in the flue gases of the considered boiler installations. However, the applied shares $\sigma$ of air mixing, which are in the practical range necessary for anticorrosion protection of chimneys, are small. Therefore, the temperatures $t_{\text {ori }}$ of flue gases at the outlet from the orifice are lower in comparison with the two methods described above.

It is pertinent to note that the application of the method for adding heated air is limited in practice, as a rule, due to the absence of air heaters in municipal boiler plants of small and medium capacity. The use of air heated in the heat recovery system, on the other hand, requires the use of a set of thermal methods: heating of flue gases and air mixing. Under these conditions, to implement a set of methods it is necessary to install in the heat recovery system a gas preheater and a special heat exchanger for air heating [9].

It should be noted that, according to the research results for all operating modes of the boiler plant and the applied thermal methods, the temperatures $t_{o r i}$ and the velocity $W_{o r i}$ of flue gases at the outlet from the orifice are higher for a brick chimney compared to a metal chimney $\left(t_{\text {ori }}\right.$ by $3-15 \% ; W_{\text {gir }}$ by $0.5-0.8 \%)$. This is due to the intense cooling of flue gases in the metal pipe due to the low thermal insulation properties of its shell.

Fig. 3 shows the results of calculations of the relative values of the decrease in the maximum ground-level concentrations of nitrogen oxide emissions $C_{r e l}^{\mathrm{NO}_{x}}$ and carbon monoxide $C_{r e l}^{\mathrm{CO}}$ when using the considered thermal methods.

The analysis of the results also indicates that the general trend for all considered thermal methods and chimneys is an increase in the level of relative decrease in the maximum ground-level concentrations of $C_{r e l}^{\mathrm{NO}_{x}}$ and $C_{r e l}^{\mathrm{CO}}$ emissions with an increase in the part of bypassing gases from the boiler $\chi$, share of dry and hot air mixing $\sigma$ and the level of heating of cooled gases gas preheater $\Delta t$.

According to the results of performed calculation experiments it was found that under the considered conditions by the
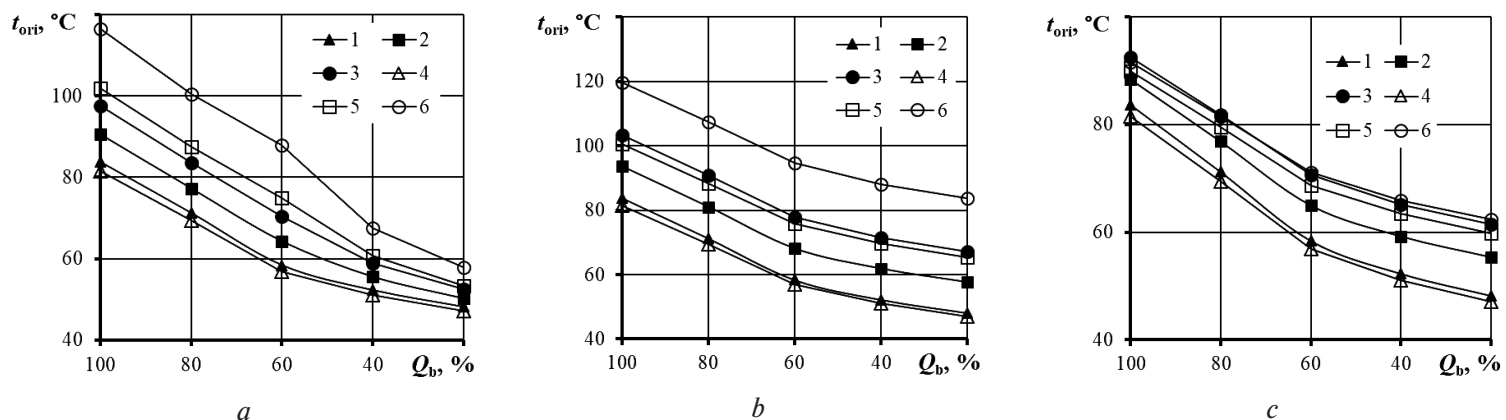

Fig. 2. Dependence of the temperature $t_{\text {ori }}$ of flue gases at the outlet from the orifice of brick (1-3) and metal (4-6) chimneys on the relative heat output of the boiler $Q_{b}$ at application thermal methods of bypassing gases $(a)$, heating gases in a gas preheater $(b)$ and adding heated air $(c)$ :

$a-1,4-\chi=0 \% ; 2-\chi=10 \% ; 3-\chi=20 \% ; 5-\chi=30 \% ; 6-\chi=50 \% ; b-1,4-\Delta t=0{ }^{\circ} \mathrm{C} ; 2-\Delta t=10{ }^{\circ} \mathrm{C} ; 3-\Delta t=20{ }^{\circ} \mathrm{C} ; 5-\Delta t=$ $=30{ }^{\circ} \mathrm{C} ; 6-\Delta t=40{ }^{\circ} \mathrm{C} ; c-1,4-\sigma=0 \% ; 2-\sigma=8 \% ; 3,5-\sigma=16 \% ; 6-\sigma=20 \%$ 

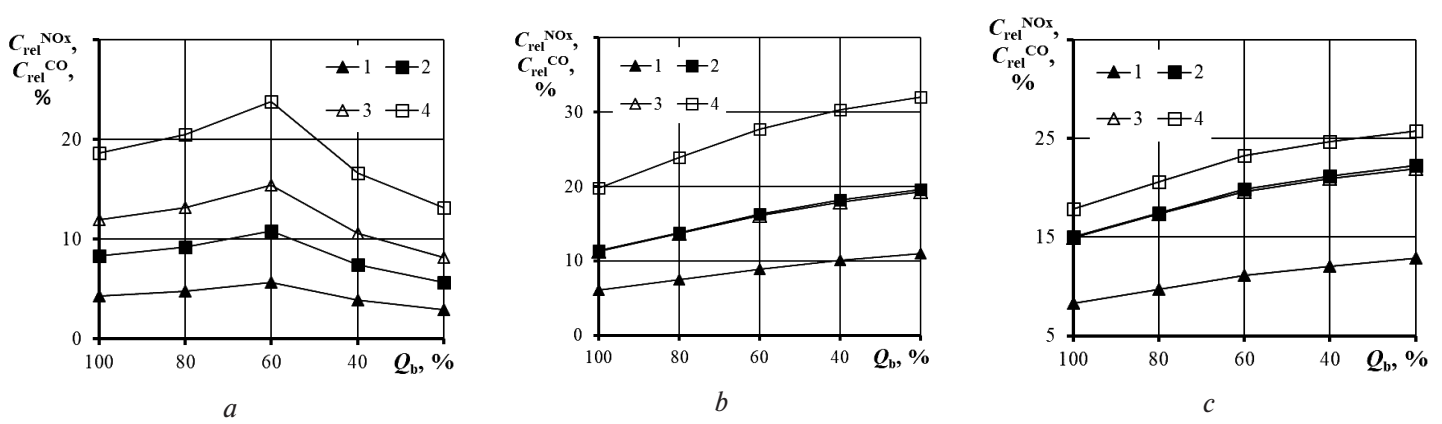

Fig. 3. Dependence of the relative decrease in the values of the ground-level concentration of nitrogen emissions $C_{r e l}^{\mathrm{NO}_{x}}$ and carbon monoxide $C_{r e l}^{\mathrm{CO}}$ at the outlet from the orifice of brick (1-2) and metal (3-4) chimneys on the relative heat output of the boiler $Q_{b}$ at application thermal methods of bypassing gases $(a)$, heating gases in a gas preheater $(b)$ and adding heated air $(c)$ :

$a-1-\chi=10 \% ; 2-\chi=20 \% ; 3-\chi=30 \% ; 4-\chi=50 \% ; b-1-\Delta t=10{ }^{\circ} \mathrm{C} ; 2,3-\Delta t=20{ }^{\circ} \mathrm{C} ; 4-\Delta t=40{ }^{\circ} \mathrm{C} ; c-1-\sigma=8 \% ; 2,3-\sigma=$ $=16 \% ; 4-\sigma=20 \%$

values of relative values of decrease in maximum ground-level concentrations of harmful emissions of $C_{r e l}^{\mathrm{NO}_{x}}$ and $C_{r e l}^{\mathrm{CO}}$, depending on the boiler mode, applied method and values of parameters $\chi, \sigma$ and $\Delta t$ the environmental efficiency of chimneys of boiler plants increases within $3-22 \%$ for a brick chimney and by $4-32 \%$ in case of using a metal chimney. That is, all other things being equal, metal chimneys are characterized by worsen operating modes relative to the levels of groundlevel concentrations of the investigated harmful emissions in comparison with brick ones. This is due to the deeper cooling of the flue gases in the metal pipe. Therefore, in order to improve the environmental friendliness and reliability of metal chimneys, it is necessary to apply structural improvements to these pipes in terms of thermal insulation of their body, or to increase the values of the parameters $\chi, \sigma$ and $\Delta t$.

The nature of the change in $C_{r e l}^{\mathrm{NO}_{x}}$ and $C_{r e l}^{\mathrm{CO}}$ is explained by the influence of the absolute values of the calculated masses of emissions of nitrogen oxides $M^{\mathrm{NO}_{x}}$ and carbon monoxide $M^{\mathrm{CO}}$ on the value of maximum ground-level concentrations of $C_{m}^{\mathrm{NO}_{x}}$ and $C_{m}^{\mathrm{CO}}(1)$, as well as the difference $\Delta t$ between the temperature of the exhaust gases at the chimney mouth $t_{\text {ori }}$ and the temperature environment $t_{a m b}$. With a decrease in the heat output of the boiler $Q_{b}$, the value of $M^{\mathrm{NO}_{x}}$ and $M^{\mathrm{CO}}$ of the indicated emissions also decreases. This is due to a decrease in fuel consumption as a result of a decrease in the heat output of the heating system with an increase in the ambient temperature $t_{a m b}$.

Regarding the change in the values of $C_{r e l}^{\mathrm{NO}_{x}}$ and $C_{r e l}^{\mathrm{CO} b}$ with an increase in the ambient temperature $t_{a m b}$ (which corresponds to a decrease in the relative heat output of the boiler $Q_{b}$ ), the gas bypassing method has differences when compared with the other two methods. In the case of applying the methods for drying gases in the gas preheater and adding heated air, a monotonic change in the relative values of the reduction in emissions of nitrogen oxides and carbon monoxide $C_{r e l}^{\mathrm{NO}_{x}}=f\left(Q_{b}\right)$, $C_{\text {rel }}^{C O}=f\left(Q_{b}\right)$ is observed depending on the boiler output $Q_{b}$. Moreover, the maximum value of the reduction of these emissions corresponds to the smallest of the considered values of the boiler output (30\%). Dependences of $C_{r e l}^{\mathrm{NO}_{x}}=f\left(Q_{b}\right)$ and $C_{r e l}^{C O}=f\left(Q_{b}\right)$ at application of the method of flue gas bypassing heat recovery exchangers have different character, namely: values of $C_{r e l}^{\mathrm{NO}_{x}}$ and $C_{r e l}^{\mathrm{CO}}$ increase with decrease in boiler output from nominal value $Q_{b}=Q_{n}$ to $Q_{b}=0.6 Q_{n}$, and then decrease in values of $C_{r e l}^{\mathrm{NO}_{x}}$ and $C_{r e l}^{\mathrm{CO}}$ with subsequent decrease in boiler output $Q_{b}$ is observed. That is, when using the method for bypassing the boiler exhaust gases past the heat recovery exchanger, the considered values of the relative reductions of harmful emissions $C_{r e l}^{\mathrm{NO}_{x}}$ and $C_{r e l}^{\mathrm{CO}}$ have maximum values in the area of $60 \%$ of the nominal boiler output. The bypass method differs from the other two methods also in finding the minimum values of $C_{r e l}^{\mathrm{NO}_{x}}$ and $C_{r e l}^{\mathrm{CO}}$ depending on $Q_{b}$. Thus, the minimum values of these values correspond to the smallest boiler output ( $30 \%$ ) with the flue gas bypassing method. For the methods for heating flue gases and adding heated air, the maximum values correspond to the nominal boiler output $Q_{n}$. This fact is explained by the fact that when implementing the method of flue gases bypass when the boiler output decreases below $60 \%$ there is a predominant influence on the value of the $C_{r e l}^{\mathrm{NO}_{x}}$ and $C_{r e l}^{\mathrm{CO}}$ values, reduction of flue gas temperature behind the boiler and hence the difference $t$ between the flue gas temperature $t_{\text {ori }}$ and ambient temperature $t_{a m b}$. Under these conditions, the addition of colder bypass gases from the boiler to the flue gases after heat recovery takes place. This difference when applying the flue gas bypass method, starting from the value of relative boiler output of $60 \%$ and further reducing it, decreases significantly more rapidly compared to the other two methods.

Based on the results of computational studies, a comparison was made of the effectiveness of the three considered thermal methods to improve the operating modes of chimneys from the point of view of improving environmental conditions. Analysis of the results shows that these methods under the considered conditions are characterized by different ecological efficiency. The best results in reducing the relative values of $C_{r e l}^{\mathrm{NO}_{x}}$ and $C_{r e l}^{\mathrm{CO}}$ are shown by the method of heating gases. The indicated values reach almost $32 \%$ for a metal chimney. The second most effective method is the method of adding heated air to the cooled flue gases. The maximum values of $C_{r e l}^{\mathrm{NO}_{x}}$ and $C_{r e l}^{\mathrm{CO}}$ at its application are about $26 \%$. The method for bypassing flue gases from the boiler past the heat recovery equipment is somewhat inferior in efficiency to the method for adding heated air. Values of $C_{r e l}^{\mathrm{NO}_{x}}$ and $C_{r e l}^{\mathrm{CO}}$ at bypassing gases do not exceed $24 \%$.

Originality. In the work, for the first time, the application of thermal methods related to the use of a number of methods of heat and humidity treatment of flue gases after heat recovery has been substantiated to improve the environmental performance of chimneys of boiler plants equipped with deep heat recovery systems.

Practical value. The practical significance of the results of the work lies in the possibility of their use in the design for boiler plants of new efficient heat recovery systems with deep cooling of flue gases, allowing to increase the efficiency of these installations by $5-8 \%$ or higher.

\section{Conclusions.}

1. The obtained research results have shown the effectiveness for improving the environmental conditions of the application of the considered thermal methods associated with the use of a number of methods of heat and humidity treatment of exhaust gases, using modern heat recovery technologies of boiler plants with deep cooling of flue gases.

2. According to the results of the studies performed, it was found that the proposed thermal methods due to the increase 
in temperature and velocity of flue gases at the outlet from the orifice of the two types of chimneys under consideration, contribute to an increase (up to $32 \%$ ) in their environmental friendliness under the conditions in question.

3. The considered thermal methods are ranked as follows: the method of heating gases in a gas preheater is the most effective, the relative value of reducing the maximum ground-level concentration of harmful emissions $C_{r e l}^{\mathrm{CO}}$ and $C_{r e l}^{\mathrm{NO}_{x}}$ reaches almost $32 \%$ for a metal chimney; the method of adding heated air is inferior to it in efficiency, the maximum value of $C_{r e l}^{\mathrm{CO}}$ and $C_{r e l}^{\mathrm{NO}_{x}}$ is about $26 \%$, and the bypassing method is even less effective, the values of $C_{r e l}^{\mathrm{CO}}$ and $C_{r e l}^{\mathrm{NO}_{x}}$ do not exceed $24 \%$.

The work was carried out under the project 1.7.890 "Development of methods and means of increasing the environmental efficiency and durability of chimneys of heat power plants".

\section{References.}

1. Bukowska, M., Nowak, K., Proszak-Miasik, D., \& Rabczak, S. (2017, October). Concept of heat recovery from exhaust gases. In IOP Conference Series: Materials Science and Engineering, 245(5), 052057. IOP Publishing. https://doi.org/10.1088/1757-899X/245/5/052057. 2. Jouhara, H., Khordehgah, N., Almahmoud, S., Delpech, B., Chauhan, A., \& Tassou, S. A. (2018). Waste heat recovery technologies and applications. Thermal Science and Engineering Progress, 6, 268-289. https://doi.org/10.1016/j.tsep.2018.04.017.

3. Terzi, R., Tükenmez, İ., \& Kurt, E. (2016). Energy and exergy analyses of a VVER type nuclear power plant. International journal of hydrogen energy, 41(29), 12465-12476. https://doi.org/10.1016/j. ijhydene.2016.02.016.

4. Mohammad Ameri Pouria Ahmadi, \& Armita Hamidi (2008). Energy, exergy and exergoeconomic analysis of a steam power plant: A case study. International Journal of Energy Research, 33(5), 499-512. https://doi.org/10.1002/er.1495.

5. Efimov, A. V., Goncharenko, A. L., Goncharenko, L.V., \& Esipenko, T.A. (2017). Modern technologies of deep cooling of fuel combustion products in boiler plants, their problems and solutions: monograph. Kharkiv: NTU "KhPI".

6. Yarovoi, S. N. (2016). Evaluation of the technical condition of metal chimneys of the Taganrog Metallurgical Plant OJSC after a long service life. Naukovyy Visnyk Budivnytstva, (3), 103-108.

7. Varnashov, V.V., Kiselyov, K. A., \& Grebnov, V. S. (2016). A study on operation modes of brick chimneys in operation. Vestnik Ivanovskogo Gosudarstvennogo Energeticheskogo Universiteta, (1), 18-26. https://doi.org/10.17588/2072-2672.2016.1.018-026.

8. Fialko, N. M., Navrodska, R. O., Shevchuk, S.I., Presich, G.A., \& Gnedash, G.A. (2017). Heat methods for protecting the gas-escape channels of boiler plants when applying heat-recovery technologies. Naukovyi Visnyk NLTU, 27(6), 125-130. https://doi.org/10.15421/40270625.

9. Fialko, N. M., Navrodska, R. O., Presich, G. A., Gnedash, G. A., \& Shevchuk, S. I. (2020). Application of an air method for protecting chimneys of boiler plants in heat recovery systems. International Scientific Journal "Internauka", 4(84). 84-87. https://doi. org/10.25313/2520-2057-2020-4.

10. Kuznetsov, N. V., Mitor, V.V., \& Dubovsky, I.E. (2020). Thermal calculation of boiler units. Normative method. Moscow: Ekolit. ISBN: 978-5-4365-0014-0.

\section{Покращення умов довкілля при застосуванні теплоутилізаційних технологій котельних установок}

\author{
Н. М. Фіалко, Р. О. Навродська, С. І. Шевчук, \\ A. I. Степанова
}

Інститут технічної теплофізики НАН України, м. Київ, Україна, e-mail: navrodska-ittf@ukr.net

Мета. Аналіз ефективності використання для газоспоживальних котельних установок із системами теплоутилізації методів тепловологісної обробки димових газів для покращення експлуатаційних режимів димових труб.

Методика. Використовувалися відомі нормативні методи теплового розрахунку котельних установок і методики щодо розсіювання у приземному шарі забруднюючих речовин, які викидаються димовими трубами цих установок. Для визначення тепловологісних показників димових газів при їх глибокому охолодженні використовувалась оригінальна методика, що розроблена в Інституті технічної теплофізики НАН України.

Результати. Досліджена ефективність використання запропонованих теплових методів для покращення умов довкілля й підвищення експлуатаційної надійності димових труб газоспоживальних котельних установок, оснащених системами глибокої теплоутилізації відхідних газів. Розглядалися методи, шо зазвичай використовуються в котельнях з метою запобігання конденсатоутворенню в димових трубах. Визначене зменшення максимальної приземної концентрації викидів оксидів азоту й вуглецю при використанні вказаних методів. Виконано порівняльний аналіз ефективності застосування пропонованих методів для цегляних і металевих димових труб у різних режимах експлуатації опалювальних котельних установок. Показано, що дані методи дозволяють суттєво (до $32 \%$ ) покращити показники екологічної ефективності димових труб в умовах скорочення на 5-8 \% обсягів використання палива в котлах.

Наукова новизна. Уперше обгрунтовано для покращення екологічних показників димових труб котельних установок із системами глибокої теплоутилізації димових газів застосування теплових методів їх тепловологісної обробки.

Практична значимість. Можливість використання результатів роботи при проектуванні теплоутилізаційних технологій для опалювальних газоспоживальних котелень.

Ключові слова: системи теплоутилізації, способи тепловологісної обробки, димові гази, шкідливі викиди, екологічна ефективність

The manuscript was submitted 08.04.21. 